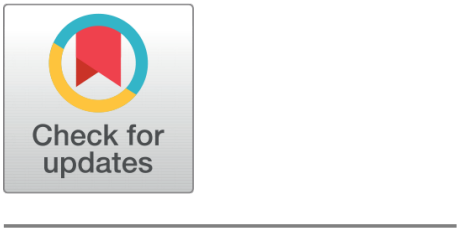

OPEn ACCESS

Received: 05.10.2021

Accepted: 01.01.2021

Published: 27.01.2021

Citation: Padronia RZ (2021) Rapid assessment of economically important species in the municipality of Concepcion. Indian Journal of Science and Technology 14(3): 208-219. https://doi.org/ 10.17485/IJST/v14i3.1808

* Corresponding author. razelpadronia@gmail.com

Funding: None

Competing Interests: None

Copyright: (c) 2021 Padronia. This is an open access article distributed under the terms of the Creative Commons Attribution License, which permits unrestricted use, distribution, and reproduction in any medium, provided the original author and source are credited.

Published By Indian Society for Education and Environment (iSee)

ISSN

Print: 0974-6846

Electronic: 0974-5645

\section{Rapid assessment of economically important species in the municipality of Concepcion}

\author{
Razel Zerrudo Padronia ${ }^{1 *}$ \\ 1 Faculty, Teacher Education Department, Northern Iloilo Polytechnic State College, \\ Concepcion Campus, Concepcion, Iloilo, Philippines
}

\section{Abstract}

Purpose: The study aims to determine the volume of pelagic fishes' catch landed in the Concepcion Fish Port after the close season. This study's formulations supported the status of marine protected areas in Concepcion's municipality, specifically in Poblacion, as to its sustainability for market and entrepreneurship. Methods: This study employed a descriptive survey research design. The participants were purposively selected fishers using commercial and municipal boats but residents of Concepcion's Municipality. The data gathering was made through documentation and calculation of fish caught and identifying local, English, and scientific names. Results/Application: Results showed that commercial and municipal fishing boats were allowed to fish in Concepcion Municipal water. The fishing gears for municipal fishing boats used were boat drive-n net (DIN) or palubog, drift gillnet (DGN) or pamu, fish trap (FT) or bobo, encircling gill net (EGN) or likos, bag net (BGN) or baskal. Furthermore, with about 31 species of different marine resources, DIM topped the list, followed by DGN in a total of 22 species, FT 11, and both EGN and BGN only recorded one specie for municipal fishing gears. While in commercial fishing gear, ST has 27 marine species, 18 for RNAC, 9 for RNFF. The records revealed 54 species of pelagic and 12 other marine organisms caught in the Concepcion waters. The top 5 pelagic fishes dominated the lists were Sardinella lemuro or Bali sardinella (Tuloy), weighing almost 52,611.5; Scolopsis taenioptera or Lattice monocle bream (Opo-opos), weighs around 3,585.1 kilogrsm. Then, Gerres oyena or Common Silver Body (Latab), 2,104.2 kilograms; Scomberomorus commerson or Narrow barred Spanich Mackerel (Tangigue), 1,708.5 kilograms; and, Selaroide leptulepsis or Yellow Stripe Scad (Balinuan), 1,457.2 kilograms. For non-pelagic, the top of the survey was Phoyololigo duvauceli or Indian squid (Lokus) weighs around 5,000 kilograms. The results showed closed season is an effective way for fish reproduction of different pelagic fishes in the Visayan Sea.

Keywords: Visayan sea; catch volume; Pelagic fish; Pelagic zone; fishing gears 


\section{Introduction}

The Philippines dubbed as the "Center of the Center," the country is located in the hotspot called the "Coral Triangle." Besides the unique coral reefs, the abundance of seagrass beds, mangrove, beach forest, diverse fishes, invertebrates, seaweeds, and other marine species, makes the country rich with biodiversity than any region in the world. Records show 468 scleractinian corals, 1,755 reef-associated fishes, 648 species of mollusks, 19 species of seagrass, and 820 species of algae. Furthermore, around 212 fish species are not complete, 731 of which are considered commercially important. Also, the country is ranked the secondhighest seagrass diversity in the world ${ }^{(1)}$.

Additionally, crabs, seaweeds, pearls, and fishes are the country's top resources ${ }^{(2)}$. However, today is a different scenario. Little by little, all these resources are depleting. The current situations, natural calamities, and human intervention are reducing our resources little by little. One problem like the El Nino caused to increase in phytoplankton biomass and coral bleaching and might lead to the fish kill, seaweed diseases, and a threat to a marine mammal.

Furthermore, many pelagic fishes started to migrate to areas with favorable conditions and disturb catch production ${ }^{(3)}$. In northern Iloilo, 7 of 11 municipalities are located in the vicinity of the Visayan Sea. Carles, Balasan, Estancia, San Dionisio, Concepcion, Ajuy, and Barotac Viejo Fishing the source of livelihood of some of the locals, but some are into illegal activities like using active gears and encroachment of commercial fishing vessel ${ }^{(4)}$. Thus, with the continuous unlawful activities in the coastal municipalities in Northern Iloilo, Province of Iloilo organized coastal resource management. This alliance is a vehicle to deliver a program to manage the marine resources in the $5^{\text {th }}$ District of Iloilo ${ }^{(5)}$. All local government units (LGUs) located within the Visayan Sea vicinity worked together to protect and preserve the remaining marine resources. Each LGU created policy and ordinances anchored on national government laws to continue and sustain diverse marine biodiversity in the district.

There is almost four fish port in Northern Iloilo, and one is located in the Municipality of Concepcion served as a fish market. The port is supplying fish products for the past decades to people within the district. Also, neighboring towns up to the city visit to buy different marine products in the municipality to sell in their respective places. Aside from that, the port is a jump-off point to several beautiful islands of the municipality. But, the fish port was destroyed during the 2013 Typhoon Haiyan ${ }^{(6)}$. Thus, the Province of Iloilo, together with the Korea International Cooperation Agency (KOICA), signed a memorandum of agreement for a 3 million dollar project to rehab the Concepcion fish port. This project includes site development, administration building, fish market, fish market public toilet, causeway, and rockwall revetment.

On the other hand, the local government unit (LGU) of Concepcion is tasked to provide utilities such as power, water, sewerage, and drainage and will also bear the costs of resettlement of affected residents ${ }^{(7)}$. With the progress coupled with state-of-the-art facilities, the fishing industry will boom once again. The economy will improve for sustainable developmenthowever, regulation about fishing on the municipal water.

As a new fishing port, no current documents were revealed about fish caught within the municipal water on the peak of the open season used as a source of food product innovations. Thus, this study was formulated. This study aims to assess economically essential fishes catch in the Municipality of Concepcion water using boats and different fishing gears.

\subsection{Visayan Sea: The treasures in the Western Visayan}

The Visayan Sea, one of the country's most significant fishing grounds, is bounded by the islands of Cebu and Negros to the south; Masbate to the north; Panay to the west; and Leyte to the east ${ }^{(8)}$. As the center of marine biodiversity on Earth and the Visayan Sea, the Philippines is our geographical heart and Earth's natural resources' crown jewel. High valued tuna species, herring, mackerel, blue swimming crab, and sardines are all found in the Visayan Sea with all forms of marine ecosystems ${ }^{(9)}$.

Memorandum of Understanding (MOU) between the Bureau of Fisheries and Aquatic Resources (BFAR) and municipalities in Northern Iloilo to impose a "no tolerance policy to fishing laws." Explicitly, this MOU is to protect the coastal resources in municipalities of Concepcion and Cales ${ }^{(10)}$. The Visayan Sea study to preserve the fish and help fishers earn a living recommends employing different management options ${ }^{(11)}$. Mangrove, corals, seagrasses, and fish habitats are the most abundant ecosystem in the Visayan Sea; thus, fishes are elsewhere ${ }^{(12)}$. Table 1 shows selected fishes' production in the Visayan Sea for 2004-2007 ${ }^{(13)}$.

Table 1. Production of selected fishes in the Visayan Sea from 2004-2007

\begin{tabular}{ll}
\hline Pelagic Fishes & Kilograms \\
\hline Sardines & $32,489,089.25$ \\
Roundscad & $3,995,017.85$ \\
Mackerels & $11,225,737.94$ \\
Achovies & $1,590,950.65$ \\
\hline
\end{tabular}


Small pelagic fishes are planktivorous fish that are commonly found in waters not exceeding 200 meters in depth. Examples of these fishes are Clupeioids (Engraulidae, Clupeidae), Scads (Carangidae), Mackerels (Scombridae), Fusiliers (Caesionidae), Flying fish (Exocoetidae), Halfbeaks (Hemiramphidae), and silversides (Atherinidae) ${ }^{(14)}$. For instance, $n$ Lingayen Gold from 2009-2013, the most catch was small pelagic such as Decapterus maruadsi, Decapterus macrosoma, Selar crumenophthalmus, Rastrelliger brachysoma, and Rastrelliger kanagurta ${ }^{(15)}$. However, in Sarangani Bay, known as rich fishing grounds for pelagic fishes, in 2008 , there are about $92 \%$ catch but declined in 2012 to almost $86 \%$. The number of species recorded is about 401 but reduced drastically to 249 species $^{(16)}$. Fishing pressure caused a declined in small-scale and commercial production ${ }^{(17)}$.

\subsection{Fishing season in the Visayan Sea}

There are two seasons in fishing within the Visayan Sea waters - the fishery closed from November 15 to February 15 and opened on March 15 and ended on October 15. Visayan governors and mayors gathered together and pledged to guard and bring back the richness of marine biodiversity in the Visayan Sea. Together with BFAR, the governors from Cebu, Iloilo, and Negros Occidental signed a covenant of agreement; together, they protect and conserve the Visayan Sea ${ }^{(9)}$.

During the closed seasons, regulated the prohibiting the fishing of sardines, herrings, and mackerels in some portion of the Visayan Seas from allowing these pelagic fishes to flourish ${ }^{(8)}$. BFAR foresees a $20 \%$ increase in fishes' production from three months fishing ban in the country's most productive fishing ground ${ }^{(18)}$. But the Visible Infrared Imaging Radiometer Suite (VIIRS) system of Oceana Philippines detected illegal fishing in the municipalities of Carles, Concepcion, Barotac Viejo, and Ajuy, and Cadiz City, Negros Occidental; and in Madridejos and Bantayan in Cebu ${ }^{(19)}$.

Overfishing and overcapacity resulted in fishing stock depletion; specifically, sardines are commonly targeted at the closed season. Sardines are the essential pelagic fishes globally and composed $13 \%$ of the total fish reproduction ${ }^{(20)}$. However, overexploitation means that fishing in the area is no longer sustainable, that fish stocks are suffering, and fishing communities are losing their livelihoods. The study finds that the best way forward would be to use various management options, including installing a marine protected area and implementing various fishing bans. The study also recommends that a single management body should be set up to oversee the implementation of this multi-pronged approach. The Visayan Sea's current state calls for immediate intervention to arrest a further decline in the marine resource quality. Any delay in addressing the problems the sea faces will worsen many fishers' problematic situation. If action is delayed until the fishery resource in the Sea collapses, then a major social crisis will be unavoidable ${ }^{(21)}$.

\subsection{Fishing in the Visayan Sea}

Table 2 shows the law and ordinances of the Municipality of Concepcion to their local marine resources.

Table 2. Law and Ordinances of the Municipality of Concepcion to protect marine resources

\begin{tabular}{ll}
\hline Laws & Content \\
\hline Section 1 Prohibition - Section 2 of FAO 167 & Unlawful to kill caught or taken fish during the closed season (Ignacio, 2019) \\
Section 100 of RA 8550 as amending RA10654 & $\begin{array}{l}\text { An offender shall be punishable and confiscating catch, gear, and administrative } \\
\text { fines (Ignacio, 2019) }\end{array}$ \\
Municipal Ordinance (Municipality of Concepcion) & $\begin{array}{l}\text { Sustainable Management Conservation and Development of Coastal and } \\
\text { Fishery Resources (Municipality of Concepcion, 2017) }\end{array}$ \\
Municipal Ordinance (Municipality of Concepcion) & $\begin{array}{l}\text { A portion of Baliguan Island and Igbon as Marine Protected Area (Tupas and } \\
\text { Cacho, 2020) }\end{array}$ \\
Municipal Ordinance (Municipality of Concepcion) & $\begin{array}{l}\text { Conduct of Mangrove Planting for Graduating Students (Tupas and Cacho, } \\
2020) \\
\text { Municipal Ordinance (Municipality of Concepcion) }\end{array}$ \\
& $\begin{array}{l}\text { Regulate the gathering and Taking of Nylon Shell in the Municipal Water (Tupas } \\
\text { and Cacho, 2020) }\end{array}$ \\
\hline
\end{tabular}

Violators penalized with a P6,000 fine, imprisonment of six months to six years depending on the gravity of the offense, and forfeiture of the catch and cancellation of fishing permits or licenses ${ }^{(18)}$. The catching of juveniles is also a threat to sardines populations; thus, enforcement to regulation on gears like the use of fine mesh nets and vessel monitoring requirement for all commercial fishing vessels recommended ${ }^{(19)}$.

There are around five million worked in the Sea's bounty in the Philippines ${ }^{(22)}$. The use of "sinsoro" and trawl is illegal fishing in the Municipality of Concepcion ${ }^{(23)}$. Also, fishers without proper pertinent papers fishing in the Copcepcion water are illegal. The fishermen come from Concepcion and neighboring towns like San Dionisio, Estancia, and Carles ${ }^{(24)}$. The Philippines is one 
of the eight countries in Southeast Asia, facing an alarming decline in marine resources. Events like overfishing that damaged coastal fish stocks; thus, poverty in the coastal areas increased rapidly. Fishing always plays a vital role in a source of income, food security, and income to many people in places like the Philippine ${ }^{(25)}$. Small-scale fisheries (SSF) connect to sustainable poverty alleviation in coastal areas ${ }^{(26)}$.

Table 3 shows the different types of commercial fishing

Table 3. Type of commercial fishing ${ }^{(27)}$.

\begin{tabular}{ll}
\hline Type & Description \\
\hline Small scale & making use of passive or active gear and utilizing fishing vessels of 3.1-20 GT \\
Medium-scale & utilizing active gears and vessels of 20.1-150 GT \\
Large scale & utilizing active gears and vessels of more than $150 \mathrm{GT}$. \\
\hline
\end{tabular}

Commercial fishing vessels are required to fish outside municipal waters beyond $15 \mathrm{~km}$ off the shoreline. They are required to secure a commercial fishing vessel license (CFVL) from the Bureau of Fisheries and Aquatic Resources (BFAR), which is subject to renewal every three years ${ }^{(27)}$. But out of 13 fishing grounds, ten are overfished ${ }^{(22)}$.

\section{Methods}

This study employed a descriptive survey research design among the fish handlers, fish brokers, and fish entrepreneurs in the Concepcion fish port. Specifically, the method used was purely a survey. The participants of this study were fishermen using commercial and municipal fishing boats residing in the Municipality of Concepcion. Also, the fish vendors and brokers purposively selected as a participant of this study.

Figure 1 displays the map of the Municipality of Concepcion and explicitly showing the activities in the fishing port.

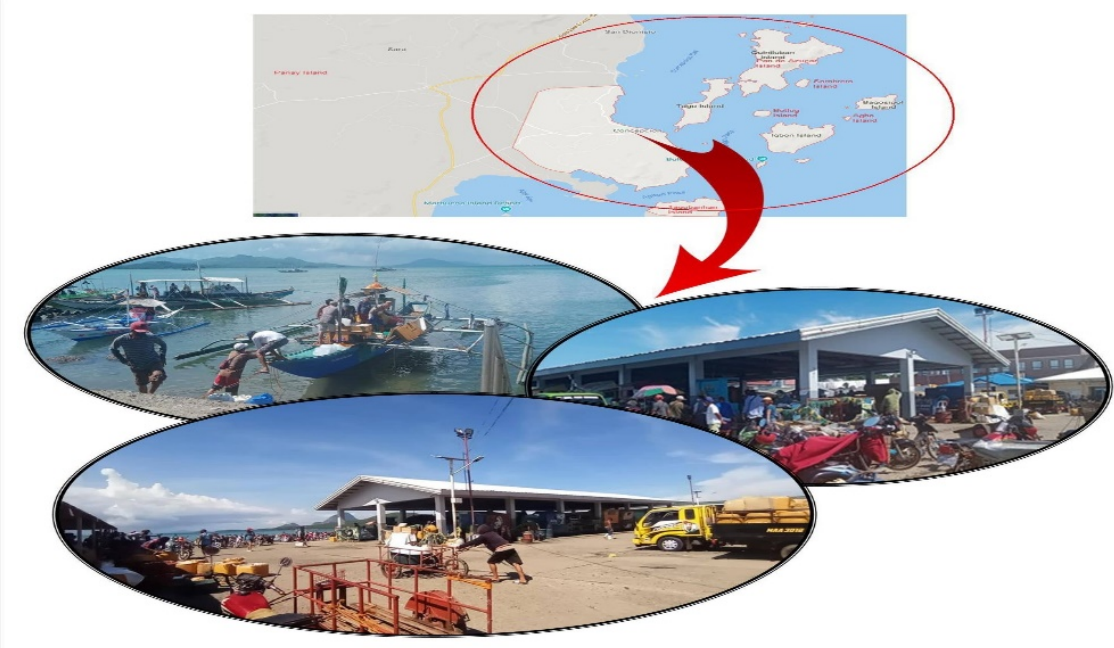

Fig 1. Map of Municipality of Concepcion showing the fishing port

Concepcion is a coastal town in the $5^{\text {th }}$ District of Iloilo, which is composed of 11 island barangays and 14 mainlands. The locals are mostly relying on farming and fishing for income and food (UCLG Committee on Social Inclusion, Participatory Democracy and Human Rights, 2010). The researchers conducted a survey of fish catch in Concepcion fish port during the last week of July and the first week of August 2018.

The instrument was a researcher-made checklist validated by experts and had undergone pilot testing to San Dionisio fish port's adjacent town. With the enumerators and the experts in fisheries, the volume of fish caught was determined. The survey was on July $1-15$ and August $1-15$. This procedure was suggested by the researchers from the Bureau of Fisheries and Aquatic Resources (BFAR). The normal days for accurate data are between 10 and 15. It made daily data gathering through documentation of estimates and calculations of fish caught and identified its species as to its categories such as scientific, English, and local names. The statistical tool utilized in this study was the frequency count and percentile rank. 


\section{Results and Discussion}

\subsection{Fishing Boat Used in Concepcion Water}

Figure 2 shows two types of boats used in fishing in the municipal water of Concepcion, Iloilo.

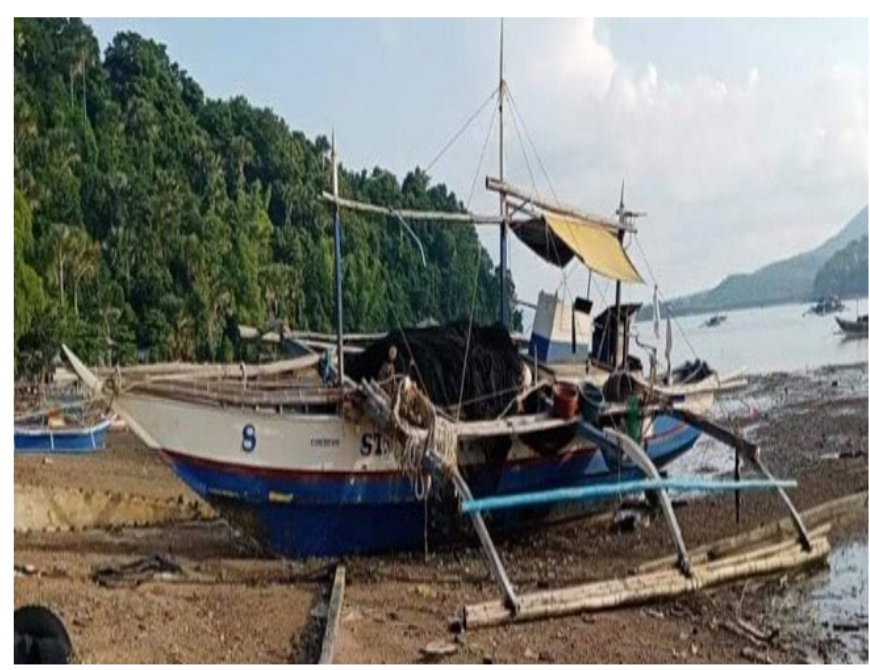

Commercial

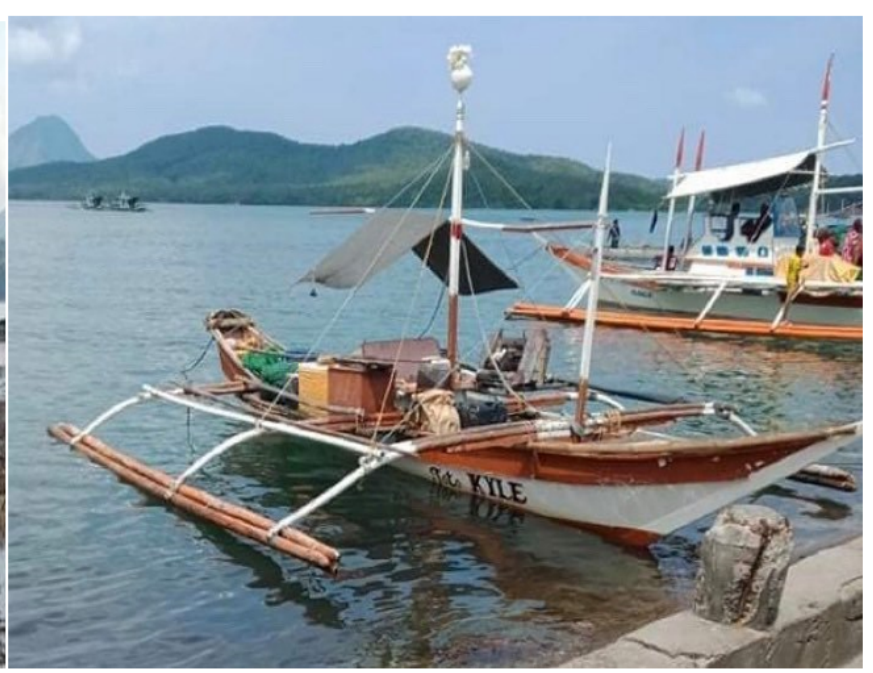

Municipal

Fig 2. Types of fishing boats docked in Concepcion fishing port

In Concepcion, the majority of the residents are into fishing as a source of income. Commercial fishing is about an activity to catch fish and other seafood products for profit ${ }^{(28)}$. There are two boats identified used for fishing in the water of the Municipality of Concepcion - these were municipal and commercial fishing boats. The LGU regulates these types of boats for fishing to protect the marine resources in the municipality. Commercial fishing used passive or active gear to catch fishes for trade and business. Simultaneously, municipal fishing is concentrated on the municipal water with around 3 GT or fewer fishing vessels ${ }^{(29)}$.

The Philippines water is exploited and overfished by many municipal and commercial fishing but triggered conflict to resource users. The use of dynamite and cyanide fishing and fishing gear like the fine mesh net are methods that contribute to rapid fish stocks and habitat degradation ${ }^{(27)}$. A municipal fishing Boat is any craft or support to fishing operations in municipal waters weighing less than three gross tonnages. And the commercial fishing boat is a vessel weighing between 3.1 tons to 150 tons of fishery species by passive or active gear within the municipal waters for trade, business ${ }^{(30)}$.

Furthermore, big commercial fishing boats engaged in "palupad" or trawl fishing, dynamic fishing, and other illegal activities are charged for illegal fishing under the Revised Fisheries Law. Thus, in 2017 around 30 commercial fishing boats were trapped and finalized by the Iloilo Provincial Bantay Dagat Task Force for engaging in such illegal acts ${ }^{(11)}$. The study on fisheries management options in the Visayan Sea revealed that fishing bans, marine protected areas, reducing commercial and municipal fishers, and establishing particular management units need to be addressed. They created a single committee to regulate any management of marine resources In areas within the Visayan Sea and be piloted in Northern Iloilo, Philippines ${ }^{(11)}$.

\subsection{Fishing gears identified to catch marine products in Concepcion water}

Figure 3shows the following gears used by commercial and municipal fishing boats to catch fish in Concepcion's municipal water.

Results showed two general classifications of gears catching the pelagic fishes in the Municipality of Concepcion, namely municipal and commercial gears. The different types and fishing gear methods significantly impact the marine ecosystem, specifically habitat and fish populations. Thus, many experts worked with assessing these particular tools ${ }^{(31)}$. Hence, the LGU is working hard to regulate fishing in the municipal water for many years. With the help of Municipal Bantay Dagat, patrolling along Concepcion bay is a regular activity. Commercial fishing gears are purse seine, ring net, bag net, and municipal fishing, gears are gill nets, hook, and lines, multiple hooks, lines drift gillnets, and others. The bottom set gillnet, bottom set longline, spear gun, and fish pot are also considered as municipal fishing gear ${ }^{(29)}$. But other coastal areas in the country like SIMBANA, 


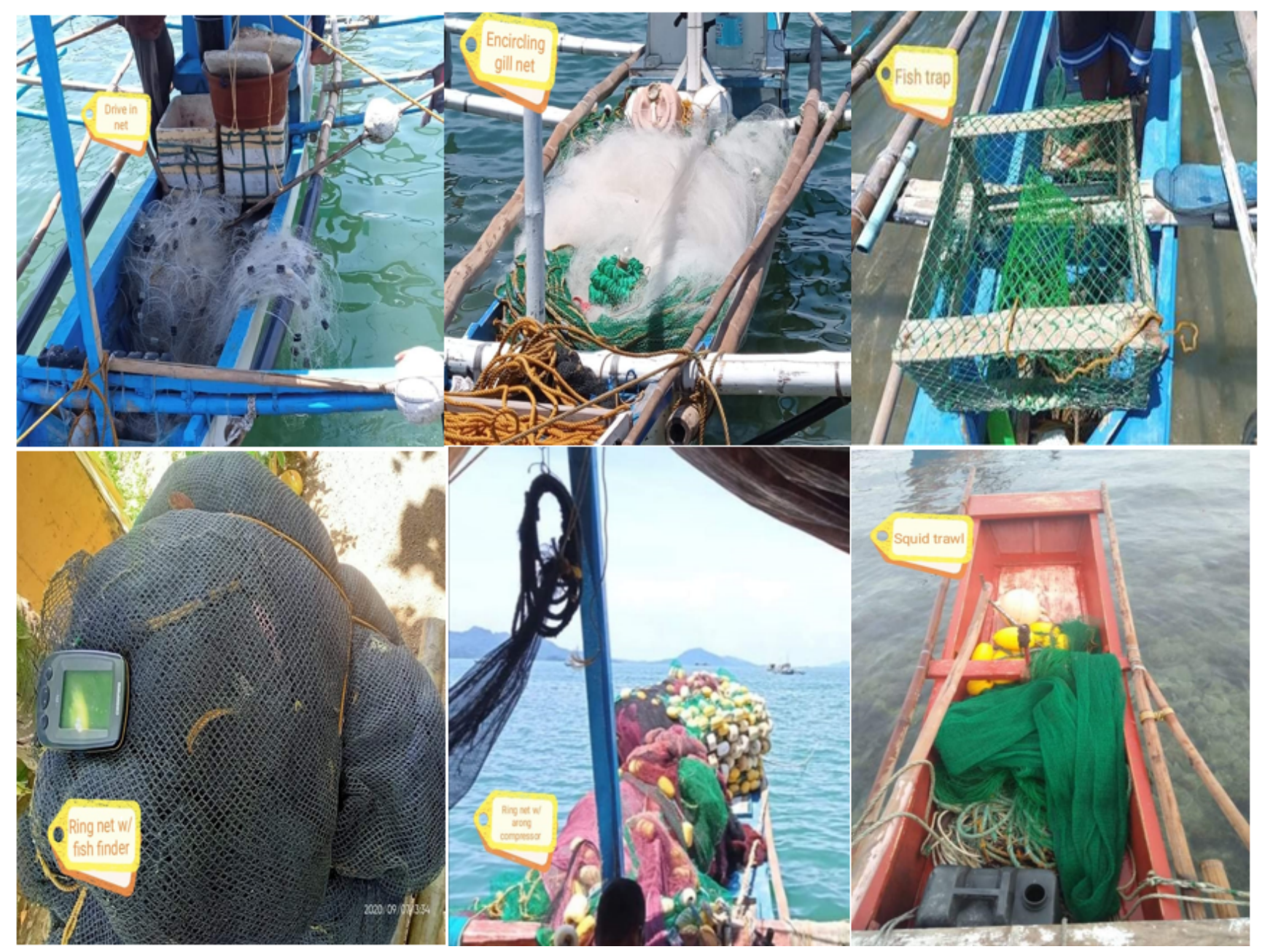

Fig 3. Gears are used by commercial and municipal fishing boats to catch fish in the municipal water

Puerto Princessa City, Rasa Island, and Nara, Palawan utilized around 16 fishing gear in the municipal waters. These gears are nets, lines, barriers and traps, hand instruments, 4, 6, 4, and 2 types. Six gears are active, and ten are passive ${ }^{(32)}$.

There were various fishing gears utilized by fishers in the Concepcion water. These fishing gears were drive-n net (palubog), drift gill net (pamu), fish trap (bobo), encircling gill net (likos), bag net (baskal), ring net with arong (likopan), ring net with fish finder (sinsoro), and squid trawl (panglukos). The drive-in-net or "palubog" in Hiligaynon is a minor fishing gear with various designs, methods, and materials among small-scale fishers but seldom used nowadays-this tool is commonly used in some parts of the Province of Iloilo ${ }^{(33)}$. While the drift gill net is locally termed as "pamu". Gillnet or "panukot" is used in shallow marine habitats ${ }^{(34)}$. Drift nets are usually used to snare gills of pelagic fishes in open-water situations with almost 26-49 feet deep nets and 90 kilometers long. But because the net is not selective, often, a large by-catch of non-target fish, sharks, turtles, seabirds, and marine mammals are some of the results of this method ${ }^{(35)}$. Fish trap is locally called "bobo," measuring roughly 2 meters by 5 meters. The process of catching marine animals is allowing the algae to grow for two weeks or set in seagrass beds ${ }^{(34)}$. Encircling Gill Net or "likos" in Hiligaynon is a gill net laid out in a circle or an arc of a circle. The grilling process hastened by frightening the fish with various devices ${ }^{(30)}$.

\subsection{Fish Catch of Different Municipal Fishing Gears}

Table 4 shows the results of marine species caught using drive-in-net as one of municipal fishing gear. 
Table 4. Drive-in-Net (DIN) municipal fishing gear

\begin{tabular}{|c|c|c|c|c|c|}
\hline No. & Local Name & English Name & Scientific Name & Weight $(\mathrm{kg})$ & $\%$ \\
\hline 1. & Latab & Common Silver Body & Gerres oyena & $2,104.2$ & $56.8 \%$ \\
\hline 2. & Gumaa & Short mackerel & Rastrelligor brachysoma & 336.5 & $9.1 \%$ \\
\hline 3. & Lawayan & Splended pony fish & Letognathus splendens & 327.0 & $8.8 \%$ \\
\hline 4. & Aso-os & Trumpeter sillago & Sillago maculata & 131.5 & $3.5 \%$ \\
\hline 5. & Tambilawan & Hound needle fish & Tylusorus crocodilus crocodilus & 128.5 & $3.5 \%$ \\
\hline 6. & Lambiyaw & Four lined terapon & Pelates quadrilineatus & 126.2 & $3.4 \%$ \\
\hline 7. & Lagaw & Golden thread fin bream & Nemipterus vingatus & 69.0 & $1.9 \%$ \\
\hline 8. & Bucaw-bucaw & Purple spotted big eye & Priacanthus rayenus & 68.8 & $1.9 \%$ \\
\hline 9. & Bagudlong & Yellow tail scad & Atule mate & 59.1 & $1.6 \%$ \\
\hline 10. & Sap-sap & Stripe pony fish & Letognathus pasciatus & 51.6 & $1.4 \%$ \\
\hline 11. & Bulao & Indian mackerel & Rasrelliger kanagurta & 48.4 & $1.3 \%$ \\
\hline 12. & Damul-damul & Whip fin pony fish & Letugnathus leuciscus & 45.5 & $1.2 \%$ \\
\hline 13. & Dalinuan & Yellow stripe scad & Selaroides leptulepis & 38.2 & $1.0 \%$ \\
\hline 14. & Opos-opos & Lattice monocle bream & Scolopsis teanioptera & 25.5 & $0.7 \%$ \\
\hline 15. & Latab & Deep bodied mojarta & Gerres erythpourus & 24.0 & $0.6 \%$ \\
\hline 16. & Bigiw & Black barred half beak & Hemiramphus far & 20.0 & $0.5 \%$ \\
\hline 17. & Talang-talang & Shrimp scad & Alepes ajedaba & 19.0 & $0.5 \%$ \\
\hline 18. & Salmonite & Sulfur goat fish & Upeneus suphureus & 14.3 & $0.4 \%$ \\
\hline 19. & Salaming & Japanese trevally & Carangoides corruleopinnatus & 10.0 & $0.3 \%$ \\
\hline 20. & Tuloy & Bali sardinella & Sardinella lemuru & 6.5 & $0.2 \%$ \\
\hline 21. & Bugaong & Jarbua terapon & Terapon jarbua & 6.1 & $0.2 \%$ \\
\hline 22. & Alatan & Yellow dot sweet lips & Diagramma pictum & 3.7 & $0.1 \%$ \\
\hline 23. & Lagaw & Yellow belly thread fin bream & Nemipterus bathybius & 3.0 & $0.1 \%$ \\
\hline 24. & Bat-og & Saw tooth barracuda & Sphyraena putnamae & 2.2 & $0.1 \%$ \\
\hline 25. & Basa & Small mouth scad & Alepes spp & 2.0 & $0.1 \%$ \\
\hline 26. & Sunog & Flat head & Platycephalus indicus & 2.0 & $0.1 \%$ \\
\hline 27. & Pagi & Blue spotted mask ray & Neutrygon kuhlli & 1.2 & $0.0 \%$ \\
\hline 28. & Lansang-lansang & Obtuse barracuda & Sphyraena obtusata & 1.0 & $0.0 \%$ \\
\hline 29. & Salmonite & Gold band goat fish & Upeneus moluclensis & 1.0 & $0.0 \%$ \\
\hline 30. & Balila & Wolf herring & Chirocentros dorab & 1.0 & $0.0 \%$ \\
\hline \multirow[t]{2}{*}{31.} & Bukaw & Diamond trevally & Alectes indica & 0.5 & $0.0 \%$ \\
\hline & & & & $3,704.5$ & \\
\hline
\end{tabular}

Drive-in net or "palubog" in Hiligaynon was another fishing gear used by the fishers in Concepcion. In this fishing gear, there were around 31 pelagic species caught and weighs a total of 3,704.5 kilograms. The most catch was a standard silver body with approximately 2,104.2 kilograms. Gerrieds is commonly found in the Indo-pacific Region and is economically valued for human consumption ${ }^{(36)}$. The remaining species identified were not as many as the first one; they weigh between 0.5 to 340 kilograms. The results showed different species available in the municipal water but very few lift due to some previous illegal activities.

Table 5 shows the survey using the drift gill net. 
Table 5. Drift gill net (DGN) municipal fishing gear

\begin{tabular}{|c|c|c|c|c|c|}
\hline No. & Local Name & English Name & Scientific Name & Weight (kg) & $\%$ \\
\hline 1. & Moong & Cardinal fish & Apogon carinatus & 259.1 & $24.4 \%$ \\
\hline 2. & Pasayan & Western king prawn & Penaeus lutisulcatus & 182.3 & $17.2 \%$ \\
\hline 3. & Bulik & Green tiger prawn & Penaeus semisulcatus & 164.4 & $15.5 \%$ \\
\hline 4. & Bagolan & Cuttle fish & Sepia lucidas & 82.1 & $7.7 \%$ \\
\hline 5. & Lokus & Indian squid & Photololigo duvauceli & 79.7 & $7.5 \%$ \\
\hline 6. & Sonug & Flat head & Platycephacus indicus & 62.0 & $5.8 \%$ \\
\hline 7. & Lampirong & Asian moon scallop & Ammussium pleuronectes & 50.8 & $4.8 \%$ \\
\hline 8. & Palad & Tufted sole & Brachirus muelleri & 49.1 & $4.6 \%$ \\
\hline 9. & Pugita & Octopus & Octopus spp & 40.0 & $3.8 \%$ \\
\hline 10 & Pasayan & Endeavour shrim & Metapenaeus endeavouri & 26.9 & $2.5 \%$ \\
\hline 11. & Opos-opos & Lattice monocle bream & Scolopsis taenioptera & 16.7 & $1.6 \%$ \\
\hline 12. & Kasag & Blue swimming crab & Portunus pelagicus & 16.3 & $1.5 \%$ \\
\hline 13 & Culambutan & Big fin reef squid & Sepioteuthis lessonniana & 10.6 & $1.0 \%$ \\
\hline 14. & Kuakit & Rough shrimp & Trachypeaeus fulvus & 7.0 & $0.7 \%$ \\
\hline 15. & Pagi & Blue spotted mask ray & Neutrygon kuhlii & 6.8 & $0.6 \%$ \\
\hline 16. & Ito & Stripe eel cat fish & Plotosus linneatus & 2.5 & $0.2 \%$ \\
\hline 17. & Dalinuan & Yellow stripe scad & Selaroides leptulepis & 1.5 & $0.1 \%$ \\
\hline 18. & Salmonite & Sulfur goat fish & Upeneus suphureus & 0.5 & $0.0 \%$ \\
\hline Total & & & & $1,061.3$ & $100 \%$ \\
\hline
\end{tabular}

In the drift gill net, around 18 pelagic species were identified and almost weighed 1,061.3 kilograms. But the drift net is not selective, commonly catch non-target fish, like, shark, turtle, seabirds, and marine mammals ${ }^{(35)}$. But in the US, California is the only remaining state that allowed drift gillnet fishing. However, state lawmakers asked Pacific Fishing Marine Council and National Marine Fisheries Services to look for alternative methods. Some non-target fish, such as dolphins and mammals, were at high risk (Ritchie, 2015). But no records from the survey that this kind of fishing gear caught non-target fish. It can also show no marine animals like dolphins or mammals are found within the coastal water of the Municipality of Concepcion. Hence, the LGU must create a policy that all non-target species, specifically those about to extinct, must be returned to the ocean to reproduce.

The cardinalfish is the top with an accumulated weight of 259.1 kilograms with a little stripe eel catfish, yellow stripe scad, and sulfur goatfish with $2.5,1.5$, and 0.5 kilograms, respectively.

Table 6 shows the different marine species caught using the fish trap.

Table 6. Fish Trap (FT) Municipal Fishing Gear

\begin{tabular}{llllll}
\hline No. & Local Name & English Name & Scientific Name & Weight (kg) & $\%$ \\
\hline 1. & Opos-opos & Lattice monocle bream & Scolopsis taenioptera & $2,756.4$ & 368.8 \\
2. & Pugita & Octopus & Octopus spp & 56.4 & $11.3 \%$ \\
3. & Dawat & Crenate Swimming crab & Thalamita crenata & 29.4 & $1.7 \%$ \\
4. & Salmonite & Sulfur goat fish & Upeneus suphureus & 26.3 & $0.9 \%$ \\
5 & Nipa-nipa & Murray eel & Enchelycore schismatorhynchus & 10.7 & $0.8 \%$ \\
6. & Kasag & Blue swimming crab & Portunus pelagicus & 9.5 & $0.3 \%$ \\
7. & Lambiyao & Four lined terapon & Pelates quadrilineatus & 2.0 & $0.3 \%$ \\
8. & Lagaw & Golden threadfin bream & Nemipterus vingatus & 1.6 & $0.1 \%$ \\
9 & Alatan & Yellow dot sweet lips & Diagramma pictum & 0.3 & $0.0 \%$ \\
10 & Inid & Grensy grouper & Epinephelus tauvina & 0.3 & $0.0 \%$ \\
11. & Pugaro & Coral rock cod & Epinephelus corallicola & $3,261.7$ & $100 \%$ \\
Total & & & & & $0.0 \%$ \\
\hline
\end{tabular}


There were around eight pelagic, crabs, and octopus recorded in the survey, and the lattice monocle bream topped the list with approximately 2,756.4 kilograms. There are different techniques to use the fish trap; one is growing filamentous algae as natural baits ${ }^{(34)}$.

Table 7 shows recorded species for the encircling gill net.

Table 7. Encircling Gill Net (EGN) Municipal Fishing Gear

\begin{tabular}{llllll}
\hline No. & Local Name & English Name & Scientific Name & Weight $(\mathrm{kg})$ & $\%$ \\
\hline 1. & Tuloy & Bali sardinella & Sardinella lemuru & $40,670.0$ & $100 \%$ \\
\hline
\end{tabular}

The encircling gillnet recorded one pelagic fish that catches 40,670 kilos - this is "Tuloy "in Hiligaynon, with a scientific name Sardinella lemuru, an English name Bali sardinella.

Table 8 shows recorded species for the Bag Net.

Table 8. Bag Net (BGN) Municipal Fishing Gear

\begin{tabular}{llllll}
\hline No. & Local Name & English Name & Scientific Name & Weight $(\mathrm{kg})$ & $\%$ \\
\hline 1. & Lokus & Indian squid & Photololigo duvauceli & 664.8 & $100 \%$ \\
\hline
\end{tabular}

Indian squid is the predominant catch in bag net with around 664.8 kilograms. Squid are commercially abundant and significant marine resources and are characterized by a short life span occurring at a depth between 30 and 170 meters ${ }^{(37)}$.

Hanging squid pots, squid jigs, drive-in net, and spear by slingshot are the gears used in squid fishery in Caraga Bay ${ }^{(38)}$.

Table 9 shows the survey using the drift gill net

Table 9. Drift Gill Net (DGN) Municipal Fishing Gear

\begin{tabular}{llllll}
\hline No. & Local Name & English Name & Scientific Name & Weight $(\mathrm{kg})$ & $\%$ \\
\hline 1. & Tangigue & Narrow barred Spanish mackerel & Scomberomorus commerson & $1,657.7$ & $89.0 \%$ \\
2. & Bagis & Shark & Carcharhinus sorrah & 148.2 & $8.0 \%$ \\
3. & Awa & Giant herring & Elops hawaiensis & 50.0 & $2.7 \%$ \\
4. & Bagis & Silky shark & Carcharhinus falcifornes & 6.9 & $0.4 \%$ \\
Total & & & & $1,862.8$ & $100 \%$ \\
\hline
\end{tabular}

Gillnet, hook and line, multiple hook and line, and drift gillnet are considered primary municipal fishings gears ${ }^{(29)}$.

\subsection{Commercial Fishing Gears Used in Concepcion Waters}

On the other hand, under the commercial gears, there were three (3) types of gears that were identified, namely: Squid trawl (ST), Ring net with arong compressor (RNAC), and Ring net with fish finder (RNFF).

Table 10 shows the different marine species caught by squid trawl.

Table 10. Squid Trawl (ST) Commercial fishing gear

\begin{tabular}{llllll}
\hline No. & Local Name & English Name & Scientific Name & Weight (kg) & $\%$ \\
\hline 1. & Lokus & Indian squid & Photololigo duvauceli & $4,172.7$ & $41.5 \%$ \\
2. & Salmonite & Freckled goat fish & Upeneus tragula & $1,247.5$ & $1,207.5$ \\
3 & Tabilos & Elongated pony fish & Letognathus elongatus & 875.0 & $12.0 \%$ \\
4 & Lawayan & Splended pony fish & Letognathus splendens & 787.5 & $7.7 \%$ \\
5. & Opos-opos & Lattice monocle bream & Scolopsis taenioptera & 490.0 & $4.9 \%$ \\
6 & Damul-damul & Whip fin pony fish & Letugnathus leuciscus & 350.0 & $3.5 \%$ \\
7. & Palid-palid & Pugnose pony fish & Secutor indicus & 157.5 & $1.6 \%$ \\
9 & Bucaw-bucaw & Purple spotted big eye & Priacanthus rayenus & 153.7 & $1.5 \%$ \\
10 & Culambutan & Big fin reef squid & Sepioteuthis lessonniana & 140.0 & $1.4 \%$ \\
11 & Sunog & Flat head & Platycephalus indicus & 70.0 & $0.7 \%$ \\
12 & Dalinuan & Yellow stripe scad & Selaroides leptulepis & 70.0 & $0.7 \%$ \\
13. & Salmonite & Sulfur goat fish & Upeneus suphureus & 70.0 & $0.7 \%$ \\
14. & Salmonite & Yellow striped goat fish & Upeneus moluclensis & & \\
\hline
\end{tabular}

Continued on next page 


\begin{tabular}{llllll}
\hline \multicolumn{2}{c}{ Table 10 continued } & & & \\
\hline 15 & Putian & Malabar trevally & Carangoides malabaricus & 55.8 & \\
16 & Ito & Stripe eel cat fish & Plotosus linneatus & 52.5 & $0.6 \%$ \\
17 & Alatan & Yellow dot sweet lips & Diagramma pictum & 40.7 & $0.5 \%$ \\
18 & Bukan & Diamond trevally & Alectes indica & 29.6 & $0.4 \%$ \\
19 & Bansa & Pick handle barracuda & Sphyraena jello & 25.3 & $0.3 \%$ \\
20 & Bat-og & Saw tooth barracuda & Sphyraena putnamae & 25.2 & $0.3 \%$ \\
21 & Pasayan & Western king prawn & Penaeus lutisulcatus & 18.8 & $0.3 \%$ \\
22 & Lagaw & Golden thread fin bream & Nemipterus vingatus & 10.0 & $0.2 \%$ \\
22 & Lampirong & Asian moon scallop & Ammussium pleuronectes & 6.2 & $0.1 \%$ \\
24 & Kasag & Blue swimming crab & Portunus pelagicus & 3.7 & $0.1 \%$ \\
25 & Inid & Grensy grouper & Epinephelus tauvina & 2.4 & $0.0 \%$ \\
26 & Bulik & Green tiger prawn & Penaeus semisulcatus & 2.1 & $0.0 \%$ \\
27 & Tangigue & Narrow barred Spanish mack- & Scomberomorus commerson & 1.8 & $0.0 \%$ \\
\multicolumn{1}{l}{ Total } & & erel & & $10,065.5$ & $0.0 \%$ \\
\hline
\end{tabular}

Squid Trawl or "panglukos" caught 10,065.5 kilos of different pelagic fish, of which Indian squid, locally known as locus with the scientific name of Photololigo duvauceli under the family name of loliginidae with 4,172.7 kilos got the highest volume of catch with (41.46\%). The RNAC caught 7,848 kilos of varied species of pelagic fish. Bali Sardinella or Tuloy with scientific name Sardinella lemuru under the family of clupeidae with a catch volume of 3,360 kilos comprising (42.81\%). Then, 3 . Ring Net with Fish Finder (RNFF) caught 11,573.5 kilos, Bali Sardinella or Tuloy with scientific name Sardinella lemuru under the family of clupeidae with a catch volume of 8,575 kilos with $(73.65 \%)$.

Table 11 shows the 18 species caught using the ring net with arong compressor

Table 11. Ring net with arong compressor (RNAC) Commercial fishing gear

\begin{tabular}{|c|c|c|c|c|c|}
\hline No. & Local Name & English Name & Scientific Name & Weight (kg) & $\%$ \\
\hline 1. & Tuloy & Bali sardinella & Sardinella lemuru & $3,360.0$ & $42.8 \%$ \\
\hline 2 & Dalinuan & Yellow stripe scad & Selaroides leptulepis & $1,347.5$ & $17.2 \%$ \\
\hline 3. & Ilak & Black pomfret & Parastromateus niger & $1,023.5$ & $13.0 \%$ \\
\hline 4 & Tabagak & Gold stripe sardinella & Sardinella gibbosa & 840.0 & $10.7 \%$ \\
\hline 5. & Basa & Small mouth scad & Alepes spp & 411.5 & $5.2 \%$ \\
\hline 6. & Bansa & Pick handle barracuda & Sphyraena jello & 169.0 & $2.2 \%$ \\
\hline 7 & Talang-talang & Shrimp scad & Alepes ajedaba & 140.0 & $1.8 \%$ \\
\hline 8 & Gumaa & Short mackerel & Rastrelligor brachysoma & 52.5 & $0.7 \%$ \\
\hline 9. & Damul-damul & Whip fin pony fish & Letugnathus leuciscus & 52.5 & $0.7 \%$ \\
\hline 10. & Pandawan & Cobia & Rachycentron canadus & 49.5 & $0.6 \%$ \\
\hline 11 & Tangigue & $\begin{array}{l}\text { Narrow barred Spanish mack- } \\
\text { erel }\end{array}$ & Scomberomorus commerson & 49.0 & $0.6 \%$ \\
\hline 12. & Bat-og & Saw tooth barracuda & Sphyraena putnamae & 35.0 & $0.4 \%$ \\
\hline 13. & Bagudlong & Yellow tail scad & Atule mate & 17.5 & $0.2 \%$ \\
\hline 14. & Marot & Short fin scad & Decapterus macosoma & 17.5 & $0.2 \%$ \\
\hline 15. & Palid-palid & Pugnose pony fish & Secutor indicus & 17.3 & $0.2 \%$ \\
\hline 16. & Bukaw & Diamond trevally & Alectes indica & 5.0 & $0.1 \%$ \\
\hline 17 & Putian & Malabar trevally & Carangoides malabaricus & 2.1 & $0.0 \%$ \\
\hline 18. & Alatan & Yellow dot sweet lips & Diagramma pictum & 2.0 & $0.0 \%$ \\
\hline Total & & & & $7,848.0$ & $100 \%$ \\
\hline
\end{tabular}

Ring net with arong or termed as "likopan" was another commercial fishing gear. This fishing gear caught a total of 7,848 kilograms composed of 18 different marine species.

Table 12 represents the marine species caught using a ring net with a fish finder. 
Table 12. Ring net with fish finder (RNFF) commercial fishing gear

\begin{tabular}{llllll}
\hline No. & Local Name & English Name & Scientific Name & Weight $(\mathrm{kg})$ & $\%$ \\
\hline 1. & Tuloy & Bali sardinella & Sardinella lemuru & $8,575.0$ & $74.1 \%$ \\
2 & Lawayan & Splended pony fish & Letognathus splendens & 910.0 & $7.9 \%$ \\
3 & Gurayan & Indian anchovy & Stolephorus indicus & 770.0 & $6.7 \%$ \\
4 & Damul-damul & Whip fin pony fish & Letugnathus leuciscus & 595.0 & $5.1 \%$ \\
5 & Lobo-lobo & Anchovy & Stolephorus spp & 455.0 & $3.9 \%$ \\
6 & Tabagak (lapad) & Fimbriated sardine & Sardinella fimbriata & 210.0 & $1.8 \%$ \\
7. & Palid-palid & Pugnose pony fish & Secutor indicus & 35.0 & $0.3 \%$ \\
8 & Bansa & Pick handle barracuda & Sphyraena jello & 19.0 & $0.2 \%$ \\
9. & Bukan & Diamond trevally & Alectes indica & 4.5 & $0.0 \%$ \\
Total & & & & $11,573.5$ & $100 \%$ \\
\hline
\end{tabular}

The ring net with a fish finder is called "sinsoro." There were nine species caught in the ring net with around 11,573.5 kilograms. But Bali sardinella, with almost 8,575.00 kilograms, topped the list.

Most of the marine resources caught using different gears were all found in the reefs or near the reefs, and almost were pelagic fishes.

\section{Conclusion}

Two types of fishing boats were allowed in Concepcion waters; commercial and municipal fishing boats. The fishing gears used were drive-n net (palubog), drift gill net (pamu), fish trap (bobo), encircling gill net (likos), bag net (baskal), ring net with arong (likopan), ring net with fish finder (sinsoro), and squid trawl (panglukos). There were 31 more or fewer types of pelagic fishes commonly caught in Concepcion's municipal waters and eventually landed in Concepcion fish port. Furthermore, an estimated 47,520.60 kilos of the volume of catch using municipal fishing gears and an estimated 29,487 kilos of assorted types of pelagic fishes were caught within fourteen days using commercial gears the open season. The two general types of gears identified in the municipality of Concepcion that were utilized in catching different species of pelagic fishes are commercial and municipal gears. Sardinella lemuru, Bali Sardinella, Tuloy marked a substantial catch compared to other types of pelagic fishes that were caught during the open season. The Encircling gill net (municipal fishing gear) and the Ring net with "arong" compressor (commercial fishing gear) that operated during the open season contributed a lot to the increase of catch volume of the said season. The entrepreneurs were encouraged to make interventions during open season to preserve the "tuloy" stock for future use. The local officials will be vigilant in controlling the commercial and municipal fishing gear vessels in catching the appropriate place of municipal water coverage. The study results will be disseminated to the academe for product development of and fish consumers on the awareness of the status of the fish catch of pelagic fishes in the municipal waters of Concepcion.

\section{Acknowledgment}

The researcher would like to extend her appreciation to Dr. Fernan Penoero Tupas of the Northern Iloilo Polytechnic State College-Main Campus for his encouragement and support. Also, his expertise in enhancing this research output.

\section{References}

1) Dorence E. Philippines Marine Biodiversity: A Brief Profile. 2016. Available from: https://haribon.org.ph/philippine-marine-biodiversity-a-brief-profile/.

2) Morgan L. List of Natural Resources in the Philippines. 2020. Available from: https://traveltips.usatoday.com/rare-plants-animals-philippines-63177. html.

3) Damatac AM, Santos M. Possible Effect of El Nino on some Philippines Marine Fisheries Resources. Philippine Journal of Science. 2016;145(3):283-295.

4) News PN. Iloilo Illegal Fishing Hotspot. 2019. Available from: https://www.panaynews.net/n-iloilo-illegal-fishing-hotspot/.

5) Momblan G. Iloilo Guv Eyes Coastal Resources Management Alliance. 2019. Available from: https://www.pna.gov.ph/articles/1086362.

6) News P. What Will Concepcion's new Fish Port look like?. 2017. Available from: http://www.panaynews.net/what-will-concepcions-new-fish-port-looklike/.

7) Conserva LH. KOICA Releases Initial Fund for Concepcion Port Rehab. 2020. Available from: http://iloilo.gov.ph/infrastructure/koica-releases-initialfund-concepcion-port-rehab.

8) Cuz IRS. BFAR 7, sets 3 Months Fishing Ban at a Portion of Visayan Sea. 2019. Available from: https://cebudailynews.inquirer.net/269669/bfar-7-sets3-month-fishing-ban-at-a-portion-of-visayan-sea.

9) Mongaya C. Guardians of the Sea Convened. 2017. Available from: https://ph.oceana.org/press-center/press-releases/guardians-visayan-sea-convened. 10) Ferrer C. Task Force formed to protect marine resources in Iloilo. 2017. Available from: https://www.pna.gov.ph/articles/1012946. 
11) Ferrer AJD. Fisheries Management Options for Visayan Sea, Philippines: The Case of Northern Iloilo. 2016. Available from: https://doi.org/10.1007/978981-10-014/-3\protect\$relax |lnot\$_14.

12) Tupas FP, Matsuura T. Integrating arts in the basic science curriculum: In the context of local marine resources in the Visayan Sea. Indian Journal of Science and Technology. 2020;13(11):1248-1548. Available from: https://doi.org/10.174851/IJST/v13i11.149967-2020.

13) Santos MD. Seasonality of commercially important pelagic fishes in the Philippines: overfish or climate change. 2011. Available from: http://www.wamis. org/agm/meetings/wofish11/S2-Santos.pdf.

14) Baclayo JM, Deligero RC, Holoyohoy LM, Bognot EC. Status of dominant small pelagic in Hinatuan Passage, Caraga Region, Philippines. International Journal of Fisheries and Aquatic Studies. 2016;4(4):286-303.

15) Gaerlan RS, Buccat FG, Ragutero F. A Review on the Status of Small Pelagic Fish Resources in the Lingayen Gulf for the Year 2009-2013. The Philippine Journal of Fisheries. 2018;25:1-13. Available from: https://dx.doi.org/10.31398/tpjf/25.1.2017c0001.

16) Emperua LL, Donia EA, Biaca MJ, Pechon RR, Pautong AT, Balonos T. The small pelagic fishes of Sarangani Bay. The Philippine Journal of Fishery. 2017;25(1):118-127. Available from: https://doi.org/10.31398/tpif/25.1.2017COO14.

17) Mequila A, Campos WL. Feeding relationship of dominant fish species in the Visayan Sea. Science Diliman. 2007;19(1):1-35.

18) News P. Closed Seasons in Visayan Sea looms. 2018. Available from: http://www.panaynews.net/closed-season-in-visayan-sea-looms/.

19) Ignacio RJN. Illegal Fishing during Closed Season detected in Visayan Sea - NGO. 2019. Available from: https://www.bworldonline.com/illegal-fishingduring-closed-season-detected-in-visayan-sea-ngo/.

20) Napata RP, Espectato LN, Serofia GD. Closed season policy in Visayan Sea, Philippines: A second look. Ocean \& Coastal Management. 2020;187. Available from: https://dx.doi.org/10.1016/j.ocecoaman.2020.105115.

21) Ferrer A. Evaluation of Fisheries Management Options for the Visayan Sea, Philippines. Economy and Environment Partnership for Southeast Asia. 2009.

22) Cameron S. Places for the Fishing in the Philippines. 2018. Available from: https://traveltips.usatoday.com/places-fishing-philippines-111507.html.

23) Nepomoceno JA. Illegal Fishers Falls in Concepcion. 2017. Available from: https://www.iloilo.gov.ph/illegal-fishing/illegal-fishers-fall-concepcioncarles.

24) Nepomoceno JA. 86 Illegal Fishers Fal in Concepcion, Carles. 2018. Available from: https://iloilo.gov.ph/tags/illegal-fishing.

25) Salayao N, Garces L, Piod M, Viswanathan K, Pomeroy R, Ahmed M, et al. Managing excess capacity in small-scale fisheries: Perspectives from stakeholders in three Southeast Asian countries Marine Policy. 2008;23(4):692-700. Available from: http://doi.org/10.1016/jmarpol.2007.12.001.

26) O'Neill ED, Crona B, Ferrer AJG, Pomeroy R, Jiddawi NS. Who benefits from seafood trade? A comparison of social and market structures in small-scale fisheries. Ecology and Society. 2018;23(3). Available from: https://dx.doi.org/10.5751/es-10331-230312.

27) Lamarca NSJ. Fisheries Country Profile: Philippines. 2020. Available from: http://www.seafdec.org/fisheries-country-profile-philippines/.

28) Science Daily. Commercial Fishing. 2020. Available from: https://www.sciencedaily.com/terms/commercial_fishing.html.

29) Mamalangkap M, Mokamad U, Ayub S. Assessment of Small Pelagic Species Landed in ARMM, Sulu Sea. The Philippine Journal of Fisheries. 2018;25(1):183-192. Available from: https://dx.doi.org/10.31398/tpjf/25.1.2017c0016.

30) Of CM. Series Of 2008 - An Ordinance Providing for the Sustainable Management Conservation and Development of Coastal and Fishery Resources of the Municipality Of Concepcion, Province of Iloilo Amending for such Purpose The Existing Fishery Ordinances Of This Municipality. Sagunniang Bayan. 2017;25(1):183-192. Available from: https://doi.org/10.31398/tpjf/25.1.2017C0016.

31) Marine Stewardship Council. Fishing Methods and Gear Types. 2020. Available from: https://www.msc.org/what-we-are-doing/our-approach/fishingmethods-and-gear-types.

32) Balisco R, Tahajudjiin C, Vigonte A. Fishing gear and their common catch in two coastal areas of Palawa, Philippines: implications to fisheries management. International Journal of Fisheries and Aquatic Studies. 2019;7(2):216-222.

33) Southeast Asian Fisheries Development Center. 2007. Available from: http://map.seafdec.org/Monograph/Monograph_philippines/Drive\%20in\%20net. php.

34) Ewies AAA. Outpatient 'Acute Gynaecology Clinic' - a novel admission avoidance model to improve women care. Journal of Obstetrics and Gynaecology. 2016;36:552-554. Available from: https://dx.doi.org/10.3109/01443615.2015.1090418.

35) Drift Net: Ecological damage caused by drift nets. 2020. Available from: https://science.jrank.org/pages/2162/Drift-Net.html.

36) Shutharsan S, Sivashanth K. First Record of Three Species of Gerreids (Pisces: Perciformes) from the Jaffna Lagoon, Sri Lanka. Journal of Fisheries and Aquatic Science. 2008;3(5):334-339. Available from: https://dx.doi.org/10.3923/jfas.2008.334.339.

37) Sahrab MM, El-Sayed AY, El-Ganery AA. Fishery and population characteristics of the Indian Squids Loligo duvaucelo orbiny, 1848 from trawl survey along north-west Red Sea. The Egyptian Journal of Aquatic Research. 2015;41(3):279-285. Available from: https://doi.prg/10.1016/jejar.2015.07.003.

38) Dickson JO, Ricafrente BR. The squid fishery in Carigara Bay, Samar: catch of Photololigo duvaucelii by squid jigs and Sepioteuthis lessoniana by hanging squid pot. In: Bagarinao TU, editor. Research Output of the Fisheries Sector Program;vol. 2. Bureau of Agricultural Research, Department of Agriculture. 2007;p. 178-181. 